\title{
Evaluating the Challenges and Opportunities of the Use of Military Diplomacy in Intrastate Conflict Management in the Horn of Africa.
}

\author{
Charles Okongo Imbiakha, ${ }^{1}$ Pontian Godfrey Okoth $^{2}$ and Edmond Maloba Were ${ }^{3}$ \\ ${ }^{1}$ Department of Peace and Conflict Studies \\ Masinde Muliro University of Science and Technology, Kenya \\ ${ }^{2}$ Department of Peace and Conflict Studies \\ Masinde Muliro University of Science and Technology, Kenya \\ ${ }^{3}$ Department of Political Science and Peace Studies
}

Kisii University, Kenya

\begin{abstract}
Military diplomacy is increasingly relied on in the management of intra state conflicts globally. Far more common and controversial is the issue of combat troops to help end fighting in an intractable conflict. The Horn of Africa is an epitome of intractable regional intrastate conflicts that have attracted international, regional and even individual state military and humanitarian intervention since the 1970s. The Somalia and Sudan crises provide typical examples in which such efforts have been witnessed yet they also provide a case study of successful military diplomacy by African states in states engaged in protracted intra-state conflicts. This study was conceived to evaluate the challenges and opportunities of the use of military diplomacy in intrastate conflict management in the Horn of Africa. The study was located in the rational logic theory. It was carried out among peace groups and individuals who had participated in peace processes in the Horn of Africa. These were located in Mogadishu and Kismayu, Khartoum and Juba and embassies in Kenya that represent the Horn of Africa countries. Security personnel who have had a role in the Horn of Africa peace processes at African Union (AU), Inter - Governmental Authority on Development (IGAD), East Africa Standby Force (EASF), United Nations Mission in South Sudan (UNMISS), United Nations Africa (Union) Mission in Darfur (UNAMID) and African (Union) Mission in Somalia (AMISOM) were key informants. The study used purposive sampling and snowballing to determine the sample size. Data was collected using interview schedules and questionnaires which were analyzed using Concurrent Nested (Embedded) Design. Secondary data were gathered and reviewed from Journals, books and published proceedings that corroborated the primary data. The findings indicate that the obscurity of the military and the rubric in the understanding of military diplomacy poses a challenge for the military to influence intrastate conflicts in the Horn of Africa. This is compounded by other challenges including the Cold War mentality that has made the region to witness a series of foreign activities leading to militarization of the Horn of Africa with establishment of military bases in the Horn of Africa. Peace support operations are expensive to manage yet the missions undertaken in the Horn of Africa lack sustainable source of funds and instead over rely on foreign funding and goodwill. With no sufficient funds, buying equipment and paying the staff becomes a big challenge. Emerging threats and clan dynamics are actualities that the use of military diplomacy was found to face as a challenge. To change these challenges into opportunities requires rational logic from all stakeholders in the conflict management process
\end{abstract}

\section{Introduction}

Most conflicts in Africa, Asia and Latin America were viewed through the ideological lenses of the Cold War. The wars in Burma, the Philippines, Colombia, Guatemala and Cambodia involved communist rebels, who in some form received support from the Soviet Union or China, while the governments received US 
support. In fact, the Cold War rivalry influenced several territorial conflicts as well, including Iraq, Palestine and in several Burmese conflicts. The conflicts in the Horn of Africa have witnessed intense international attention as competing powerful states establish military bases. In fact, this is akin to militarization of the entire Horn of Africa.

In this context, third party involvement in the form of facilitative mediation, problem solving workshops, training in conflict resolution and post conflict rehabilitation, are the tools available for international actors. These initiatives require a non-partisan third party role in the conflicts and are designed to deal with trust and perception related matters that cripple relationships.

For instance there have been multilateral peace-building initiatives which have attempted to resolve conflicts within the region through internal transformation of state actors from authoritarian violent actors who pose the greatest threat to their citizens into more democratic, participatory and peaceful states. Therefore, this provides an opportunity for countries within the region need to focus on their domestic peace and security challenges so that they can build strong and sustainable diplomatic relations with other countries.

The Intergovernmental Authority on Development (IGAD) is the most important regional organization in the Horn of Africa. Although IGAD has tried to use key instruments involving both the traditional aspects of diplomacy, as well as the informal aspects of public diplomacy to resolve conflicts in the region, conflicts are the order of the day. As interventions continue to occur, the role of external interventions has come under scrutiny in terms of its effects on the frequency, duration and intensity of conflicts.

Whereas militaries are traditionally associated with playing a combat role, this is currently changing thus allowing for the practice of military diplomacy. This has a direct impact on foreign policy through other means as opposed to the traditional sense of the use of the military means which now is often considered as the last resort. Therefore, with the foregoing trend, it thus seems logical to argue that military diplomacy is emerging as a form of traditional diplomatic practice by states. Military diplomacy has greater emphasis on soft power providing the required alternative to the traditional diplomatic practice in conflict management. It is often used in different meanings that differ from one related phenomena to another such as gunboat diplomacy or coercive approach through military diplomacy tools including condign, compensatory and conditioning power which are visible and objective. The conditioned power echoes the role of social relations in intra state conflict where explicit conditioning is the acceptance of authority, thus, the submission to the will of others, becomes the higher preference of those submitting. This preference can be deliberately cultivated by persuasion or education. Or it can be dictated by the culture itself; the submission is considered to be normal, proper, or traditionally correct. This is implicit conditioning. No sharp line divides one from the other; explicit conditioning shades by degrees into implicit conditioning.

\section{Literature Review}

Military diplomacy as a concept has gained relevance considering that diplomacy has experienced a significant transformation particularly in the last decades of the $20^{\text {th }}$ century. Military diplomacy performs several functions including a strong commitment to economic investment in the future of disparate regions to enhance partnerships within those regions. It equally helps to generate sustained diplomatic efforts, with military diplomacy taking the centre stage in a region held hostage by conflict (Healy, 2008). Specific reference has been made to the erosion of the barrier of sovereignty which has cushioned states against interference in their internal affairs by other states and non-state actors (Migue, 2014). It is contextualized not only within the realm of defense diplomacy, but also within the wider framework of a country's diplomacy as exemplified in the foreign policy. It can also be considered as one of the tools of a country's diplomatic practice in furtherance of its foreign policy objectives.

Military diplomacy is mainly carried out by the representatives of the Defence department, as well as other state institutions, aimed at pursuing the foreign policy interests of the state in the field of security and defence policy, and whose actions are based on the use of negotiations and other diplomatic instruments to perform several functions. Through these efforts, among others, the military units participate in carrying out diplomatic missions whether bilateral or multilateral exercises with other countries require rational logic. For instance, multilateral military diplomacy has been one of the international community's first major attempts to respond to a dangerous new challenge in the Post-Cold War era (Lyons and Samatar, 1995).

It is true that the concept of diplomacy has elicited conceptual difficulties as has been expressed by different scholars. Diplomacy is constantly changing and new challenges are emerging that need addressing. This is 
critical as it will help shed light on the challenges of military diplomacy influencing intra-state conflict management in the Horn of Africa.

According to Wallin (2015), efforts to explain the international military presence in Afghanistan via leaflets depicting the 9/11 attacks ran into trouble. According to him, research performed by the International Council on Security and Development in 2010 indicated that $90 \%$ of men in Helmand and Kandahar did not see a link between the 9/11 attacks and the international military presence in Afghanistan (Wallin, 2015).

After World War I, a new form of diplomacy evolved as a challenge to traditional diplomacy. Traditional diplomacy was accused of having failed to prevent war owing to its secretive nature. Other than the secrecy, the diplomats of traditional diplomacy were seen as members of a closed social elite tracing their roots to the aristocracy of medieval Europe (Berridge, 2005).

While roughly $2 / 3$ of interviewees could recognize photos of the World Trade Centre being struck by aircraft, they could not connect it to the $9 / 11$ attacks or the justification for the military entry into Afghanistan. This disconnect demonstrates that while leaflets dropped in Afghanistan created familiarity with the image, the lack of literacy or rational logic resulted in an inability to understand what the images were about. Much of the problem with regard to the leaflet campaigns revolves around fundamental misunderstandings of the target audience. The concept of military diplomacy in itself poses a challenge in the use of military diplomacy influencing intrastate conflict management in the Horn of Africa.

From cultural misunderstandings, to language, to inabilities to collect appropriate metrics, these issues render many of these military diplomatic efforts ineffective at best and harmful at worst. This speaks to the fundamental challenges of operations like Kenya's Operation Linda Nchi (Protect the nation) met at the time of its launch. Similarly, the UN missions in Sudan have been facing challenges, ranging from cultural misconceptions to condemnation about biased activities. Further, compounding the communications challenges, according to Wallin (2015), leaflets posed, there has been criticism over what they actually accomplish. While some may be confounded at the premise of a good intentioned leaflet being harmful, leaflets circulated by coalition troops in Afghanistan put aid workers at risk.

It is because of the challenges posed to the use of military diplomacy that Swistek (2012) asserts that the German Navy developed a field of activities that were often grouped together under the rubric; Ambassador in Blue. This approach never achieved the status of a complete conception, but with several individual and internal naval tasking, it represented a combination of activities carried out since the 1970s. A major pillar in this field of diplomatic activity was and is related to visits by German naval ships to foreign countries. The duty for the ships engaged in these visits is to represent Germany through hosting foreign officials, representing developments in German ship building and naval warfare technology, provide support for training efforts for foreign naval personnel, provide a platform for German senior government and military officials, and deliver donations from governmental as well as non-governmental organizations to foreign development projects. These activities supported the work of the German Defense or Naval Attache in the foreign country, and were focused on creating improved relations, supporting a range of development programs, providing a better understanding of German politics, as well as establishing business relations between these countries and Germany.

According to Emma (2012), the postures of the countries that form the Horn of Africa provide a challenge to diplomatic efforts. She cites an example of the reign of Siad Barre in Somalia that had significant implications to Kenya's national security posture. The call of irredentism continued under his watch as the region became destabilized, following Somali's military buildup from the East and the consequent Ogaden War (Emma, 2012).The failed-state status of Somalia saw the deterioration of security and the paralysis of state functions in what Menkhaus calls, the tragedy in Five Acts (Menkhaus, 2007).

Multilateral military interventions in the Horn of Africa and specifically in Somalia has been one of the international community's first major attempts to a dangerous new challenge in the Post- Cold War era resulting from state collapse and social disintegration. Efforts to redeem Somalia spearheaded by the United Nations in a number of initiatives proved futile (Bradbury, 1994). Operation Restore Hope under the United Nations International Task Force (UNITAF) in 1992, the expanded UN role in Somalia in 1993 under United Nations Operation in Somalia 1(UNOSOM I and UNOSOM II) in 1995 failed to materialize as 24 peacekeepers from Pakistan and 18 Rangers from USA were killed in Mogadishu (Menkhaus, 2007). Following this debacle, the UN withdrew from Somalia and the world forgot about Somalia. This is just one 
practical example of failed conflict settlement efforts akin to other states in the Horn of Africa region like the protracted conflicts in Sudan's Darfur and South Sudan.

\section{Methodology}

The study area is the Horn of Africa (HOA); The HOA is a large extension of land that protrudes from the eastern edge of the continent of Africa lying between the Indian Ocean to the East and the Gulf of Aden to the North jutting for hundreds of kilometers into the Arabian Sea including Ethiopia, Eritrea, Djibouti, Kenya, Somalia, Sudan and Uganda which are members of (IGAD).

The Horn of Africa is a location of strategic importance globally since it is a gateway from and to the Red Sea, Gulf of Aden, Arab Gulf and the Indian Ocean. It is also the continent's gateway to Asia and Middle East with deep historical ties to India and China who present themselves as powerhouses in trade and investment deals. The peace, security and stability of the region therefore is paramount not only to Africa as a continent but also to the Arab countries and the West (Fahmy, 2006).

This study employed a mixed methods design covering the target regions including Kenya (Nairobi), Somalia (Mogadishu and Kismayu), Sudan (Khartoum), South Sudan (Juba) and Ethiopia (Addis Ababa). The total sample size for the study was 270. The specific respondents for study included; state actors (Foreign Affairs, Horn of Africa Troop Contributing Countries (TCCs), Ministry of Defense, Kenya, Sudan and Somalia Embassies, Non state actors (Media houses, Non- Governmental Organizations (NGOs), Community Based Organizations (CBOs), Civil Society) and religious institutions. The researcher considered them relevant for the study because they had experience with the central phenomenon of military diplomacy and intra state conflict management. The study used purposive and snowballing sampling to determine the settings and the participants. The data was collected using questionnaires, interview guides and Focus Group Discussion (FGD) guides. Secondary data was sourced from reading literature in secondary sources.

\section{Theoretical Framework}

The study was supported by the rational logic theory in order to evaluate the challenges and opportunities of the use of military diplomacy in intrastate conflict management in the Horn of Africa. The theory is traced back to Adam Smith in his explanation of self-interest as a motivator for economic progress in a liberal economy. It helps in analyzing political behavior from a liberal economic perspective. This argument suggests that the value of challenges at stake will determine the opportunity of the parties to pay the costs of warfare and the reluctance to cede control to the competitors. This line of thought suggests that conflicts over, for example, resource-rich or geo-strategically important territories will become protracted, as the parties will be unwilling to back down. A similar view suggests that it is not the material aspects that specify when conflicts are protracted but the function that the conflict serves in the society it impacts.

In essence, the theory aims to analyze the actions and behavior of an individual as a rational, discriminating selector who aims to maximize one's utility (Munck, 2002). It relies upon an instrumental account of rationality. Basically, this implies that when people are faced with several challenges, they tend to do what they think will have the best overall outcome or result.

The rational logic theory finds expression in what Freeman calls, 'intervention to restore order.'(Freeman, 1997). It tries to explain why political actors consistently select the most efficient ways to achieve their goals. According to Heywood (2000), rational logic proceeds through a set of assumptions and then tries to make predictions about behavior of human beings.

The assumptions of rational logic theory include; first, individuals act in their self-interest and not in the interests of others. They are considered rational, calculating choosers who seek to maximize their own utility; second, individuals have enough information about how to make the most of their preferences. These preferences come from "outside" and are not the consequences of social, cultural or historical influences; and last, preferences are transitive. Formal modeling through the use of logical and mathematical techniques is used to model the behavior of individuals from a limited set of clearly defined maxims (Heywood, 2000). According to Heywood (2000), as a tool for political analysis, rational logic theory is possibly traced back and links to the political doctrine of utilitarianism. The theorists of rational choice use a method which can be traced back to Hobbes and it is utilized in this concept of utilitarianism as it assumes that political practitioners consistently evaluate and select the most efficient means to achieve their goals. In the form of 
public choice theory, the focus is on the provision of so-called public goods in which their benefit cannot be withheld from individuals who choose not to contribute to their provision (Heywood, 2000).

During conflict transformation the key challenge is usually how to support and sustain a platform with a capacity to adapt and generate ongoing desired change while at the same time responding creatively to immediate needs. Transformational change processes must be both linear and circular. Conflict transformation is a circular journey with a purpose. Linear means that things move from one point to the next in a straight line. It is associated with a rational-logical understanding of events in terms of cause and effect. However, in the social arena, events are likely moving along broad directions not always visible from a short-term perspective. In this arena, a linear perspective requires a look at the overall direction of social conflict and the change that is sought. It a look at the patterns of interaction, not just the immediate experience, and understanding the changes in these broad patterns. Circular understanding suggests that one needs to think carefully about how social change actually develops. This notion of circularity underscores some defining elements of transformational change processes.

\section{Results and Discussions}

From the findings of the study and documentary analysis while in the field, these challenges include; ambiguity and ubiquity of the term military diplomacy itself, the perception of military diplomacy as a coercive measure, the military of the garrison mentality, the nature of the socio-political environment in the Horn of Africa (Existence of extremist groups, and failed state status), Cold war mentality (USA/China, External Policies); Bureaucratic Processes and Competing interests among TCCs.

\section{The Ambiguity and Ubiquity of Military Diplomacy.}

In a question put to the respondents on whether the military functions diplomatically in dealing with intra state conflicts in the Horn of Africa only (54) $20 \%$ were affirmative, with a majority (189)70\% being negative while (27) $10 \%$ were unsure.

This presents a case of ambiguity as it is rationally expected that in the current military operation and tactics military diplomacy ought to be evident and taking up a huge role during the conflict resolution process. Perhaps it confirms the common notion about military obscurity. A respondent interviewed in Nairobi on 16 December 2018 said:

The reason why the military and its operations is not clearly understood is because it is shrouded in secrecy...

These sentiments were further expressed by one respondent at $\mathrm{PhD}$ level interviewed in Nairobi on 17 November 2018, in further pursuit of the question, when asked the challenge in the use of military diplomacy said:

....Is there anything like military diplomacy, have militaries exercised any diplomacy or they merely use force?...

Therefore, the first challenge lies in the ambiguity and ubiquity of the understanding and application of the term military diplomacy. Many scholars like Barston (2006), Plessis (2008), and Mohani (2012) have grappled with the term military diplomacy. Its use varies from state to state.

Some scholars like Walter (2007) have tried to draw the line between public diplomacy and military diplomacy for the ease of understanding. In the nexus between public and military diplomacy, Walter argues that on one hand public diplomacy was implemented approximately a century ago as the purely civilian aspect of diplomacy, with an aim to inform foreign populations and citizens about the goals of a given country's foreign policy through the use of information and cultural programs. This also corroborates Clausewitzian philosophy and framework which held that war was a continuation of politics by other means, where the military was always linked to the diplomatic realm, but was never part of it (Clausewitz, 1968). This further compounds the problem of understanding the concept; military diplomacy.

On the other hand, military diplomacy meant simply the business of military attachés; their mission was to be the nation's eye and ears abroad in the days before satellite photography and sophisticated electronic collection techniques (Shea, 2005). A key Rwandese informant interviewed in Nairobi on 16 November 2018 said: 
.... while we are the faces of our militaries in the diplomatic cycles, people see less diplomacy in us but associate us with intelligence gathering or simply we are seen as spying for our mother countries.

Therefore, parallel to the definition of public diplomacy, the term military diplomacy/ defense diplomacy was and is still very closely linked to the role of the military attaché (Shea, 2005). The attaché, as the counterpart of the ambassador, is a diplomat in uniform with full diplomatic status whose duty was once to logically observe and assess military developments in a foreign country, as well as to maintain a close relationship with the foreign military elite. This practice emerged as part of nineteenth-century European diplomacy, and continued nearly unchanged until the mid-1980s.

It is clear from the finding that the actual understanding of the role of those expected to play the role of military diplomats is in doubt and that's why it is a challenge to use military diplomacy to influence intra state conflict management in the Horn of Africa. However, as clearly discussed in earlier chapters, in the recent years, military and public programs and means from the areas have received increased attention that have gained a more prominent status.

At the same time, the understanding and definition of the concept of security has changed since the collapse of the Iron Curtain and the breakdown of the Soviet Union. The changes that the past several decades have seen in the makeup of the international arena, particularly regarding the new constellation of alliances, revised goals of foreign policies, and altered threat assumptions, the content of public diplomacy has changed, and its targeted programs have expanded.

This study however is in conformity with Swistek (2012) thoughts that nowadays, security is defined above all by the notion of a Comprehensive Approach to Security where security is now viewed as a set of interconnections between civilian and military means and approaches, where the use of military force remains a last resort (Swistek, 2012). The UNSC Resolution 2472 of 31 May 2019 on Somalia confirms this and lays emphasis on Comprehensive Approach to Security (CAS) (UNSCR 2472 (2019)).

Another important shift in the nature and purpose of international military relations took place along with the fall of the Iron Curtain. This changed the perception of security in favour of the comprehensive approach and enhanced security, the role of the military attachés and their duties expanded as well. In addition, they are no longer the only military actor with a role to play in the area of military diplomacy. This is reinforced by the words of a Defence Attache interviewed in Mogadishu on 15 December 2018:

...I work closely with my fellow Defence Attaches and any other person and agency in the security sector. Actually our functions are comprehensive in nature but with an eye on diplomacy...

Therefore, according to Foster and Foray (2004), the term and modern perception of military diplomacy could be defined as follows: Provide forces to meet the varied activities undertaken by the Ministry of Defense to dispel hostility build and maintain trust and assist in the development of democratically accountable armed forces, thereby making a significant contribution to conflict prevention and resolution. The traditional role of the armed forces was defined by their capability and preparedness to use force and pose a threat for the purpose of defense, deterrence, compulsion, or intervention.

Against the foundations of wartime mentality, military diplomacy nowadays is primarily a peacetime activity, and has become a major task for armed forces and their responsible ministries. It is framed by cooperation among allies and other foreign countries, especially those undergoing a process of transition towards post-conflict and democratic societies, where it can be used as a tool to promote modern foreign and security policy. Under the framework of a Comprehensive Approach to Security (CAS), military diplomacy is today one of the supporting pillars.

\section{The Dynamism of Military diplomacy as a Coercive Measure}

The use of limited force to engage in coercive diplomacy was to achieve the final objective with less cost and bloodshed, less political backlash and less risk of escalation (Gregor, 2012). There were four variants of the strategy of coercive diplomacy to look at in the horn of Africa in executing this. They include the try and see, the classic ultimatum, the tacit ultimatum, and the gradual turning of the screw variant. The try-and-see variant involves making demands without a set time limit or sense of urgency where the coercer takes one small coercive threat and waits to see if it is enough to persuade the adversary before going further. (George and Simons 1994). The classic ultimatum has three parts: the demand on the opponent, a time limit, or sense of urgency, for compliance and the threat of punishment for noncompliance. The tacit ultimatum is similar to the classic ultimatum, except that the threat of force and punishment is implied. The gradual turning of 
the screw involves making threats of escalation of coercive measures from the beginning, and later incrementally increases the use of force. George and Simons (1994) argue that the strategy can shift from one variant to another during coercive diplomacy. To successfully apply the dynamism of the four variants requires use of rational logic which offers an opportunity for military diplomacy strategists.

\section{Military of the Garrison Mentality}

One of the respondents who was interviewed in Juba on 16 October 2018, and asked to state the major challenge influencing the use of military diplomacy in the Horn of Africa said that the military suffers from a 'Garrison Mentality.' The garrison mentality challenge is corroborated by the argument advanced by Edmunds (1988) that initially the military existed to protect the state against external aggression and international interests abroad. The author asserts that the sole purpose of the military was for the security of all citizens and national territory against external physical threats where any other responsibilities, either external or internal were purely contingent (Edmonds, 1988). However, some scholars like Ayoob (1995) argued that the approach was so narrow due to the many and devise roles the military have all over the world. For instance, the military in many countries in Africa and Latin America were used primarily for internal security that majorly contradicts the assumption. On the other hand, Lasswell (1998) viewed the military as specialist in violence and building on the same Janowitz (2017) argue that the military professionalization was respectively an expertise in 'directing the application of violence under certain prescribed conditions, and expertise 'in war-making and organized use of violence.

This is further, corroborated by Edmunds (2006), the roles argued by various scholars have challenges. The military have other roles they play and are not limited. For instance, the army have historically been used to play other important domestic 'nation-building' functions like being a source of cheap organized manpower for civil construction projects, providing aid to the civil community in times of crisis, and playing an overarching 'school of the nation' role to inculcate national values through conscription (Edmunds 2006).

\section{The Changing Socio-Political Environment in the Horn of Africa.}

The changing socio-political environment in the Horn of Africa poses challenges to the use of military diplomacy in the region. During the cold war, military personnel were mostly forced to involve in strat egic thinking that was dominant in the $20^{\text {th }}$ century where any of the strategies developed were guided by war. However, those strategies that were dominant were removed immediately after the end of the cold war. The action posed an opportunity for the military of what they were developed and well understood. They were forced to go back to the drawing board and review themselves for the purposes of legitimacy. In a follow question respondents were asked to explain the factors that characterize the challenging socio-political environment in the Horn of Africa Respondents provided the following characterized; increasing terrorist activities, technological surge, failed state status, climate change and changing balance of economic power. All these have had influences on the role of military diplomacy yet providing some opportunities to rethink some strategies.

\section{i. Existence of Extremist Groups}

The challenge to military diplomacy role was due to the emergency of extremists groups fanning terrorism in the globe, especially in the Horn of Africa. The August $7^{\text {th }} 1998$ and then September $11^{\text {th }} 2001$ terrorists attacks both on the US embassies in Nairobi- Kenya, Dar salaam - Tanzania and the four coordinated attacks on USA respectively totally revolutionized the military purpose and its role in diplomacy. The terrorist's attacks reinforced the existing pressures towards the development of expeditionary capabilities in reforming armed forces (Edmunds, 2006). Terrorist outfits like Al Shabaab and their antecedent local militias such as the Macwisley and Taifa have challenged conventional militaries to their will. The Macwisley is a local militia group established to protect the locals against Al Shabaab in Southern Somalia.

However, the transformation of the military in both post-cold war and September 11 terrorist act brought in new additional functions hence providing new opportunities. The military were involved in new expeditions that totally changed their roles. They were involved in war-fighting and peacekeeping apart from other services like nation-building and domestic military assistance roles (Edmunds, 2006). However, this did come with profound challenges in the use of military diplomacy in the Horn of Africa because while there is effort to exercise diplomacy towards dealing with elements like Al Shabaab and the Janjaweed, there is skewed balance between what the Statist school of thought proffers as use of military might while 
cosmopolitan school proffers the use of conventional law enforcement mechanisms including addressing the root causes of terrorism. A respondent said:

With an insurgency you cannot deal with symptoms but deal with the root causes of the insurgency...yet these root causes are deeply engrained in religious ideology.

This statement supports the cosmopolitan school which lays emphasis on addressing root causes. However, it poses a challenge to address some root causes like ideological issues which are deeply rooted in Al Shabaab. For example they consider the current Somalia government as apostate because it is supported by the West and to them western practices including sports is totally unacceptable and sources of immorality. The use of military diplomacy is further challenged by the nature and practice of terrorism and insurgencies in Somalia and Sudan respectively. These find their sanctuary in the population so much so that when they launch their operations they jell into the population. The methods they use are also quite unconventional that contravenes international Humanitarian Law of Armed Conflict. For example Al Shabaab uses crude homemade Improvised Explosive Devices indiscriminately targeting innocent civilians especially women and children.

The challenge is, therefore, that both conventional military and insurgencies need the population as the Centre of Gravity. This poses a conflictual struggle for both sides to win the adherence of the population. Therefore the compensatory and conditioning use of military diplomacy to root them out of the population using Civil Military Cooperation (CIMIC) activities is usually challenged.

The challenge caused by terrorism is compounded by the ever evolving set of opportunities in all fields of human endeavor so that the interveners have to be at par with these changes and adopt appropriate readjustment so as to remain relevant (Barry \& Woever, 2003). For example, the rebranding of the concept of diplomacy is not easy as the pace of change among some phenomena is quite rapid and this could provide a great challenge to conflict resolutions vis-à-vis management of conflicts. Omorogbe, (2011) further contends that globalization is one such aspect that has redefined intrastate relations and the practice of military diplomacy. Besides eroding the sovereignty of states in the international arena, it has also, displayed the vulnerabilities of diplomatic practice as more players (even nonstate actors) get the opportunity to join the arena that is devoid of a regulatory umpire.

\section{ii. The New Military Technology}

Militaries involved in the war-fighting Horn of Africa have had to embrace the challenge of the new military technology. Unlike in the cold war period, the current challenges to military diplomacy in the Horn of Africa had threats to the supply of strategic resources, the proliferation of weapons of mass destruction to hostile regimes or 'rogue states', regional instability caused by intrastate conflict, and the spread of international terrorism (Moscos, 2000).

The technological challenges to the military diplomacy in the Horn of Africa provides an opportunity for rethinking in the military realm for advanced force structure that would be deployed immediately there was a crisis.

The conflicts have reached certain levels of sophistication and advancement with militia's having advanced media, complex weapons and intelligence systems. For example Al Shabaab keeps shifting form the use of Improvised Explosive Devices (IEDs) to Vehicle Borne Improvised Devices (VBIEDs) to Suicide Vehicle Borne Improvised Explosive Devices (SVBIEDs) and reports of Ant-Air capability weapons. Their intelligence network is well streamlined that some have infiltrated into government. Similarly they are fast in their media activities which does not require the bureaucracies in conventional militaries to release a simple message. This explains a statement by a media respondent interviewed in Mogadishu on 20 December 2019 and said:

One would wonder how a group estimated to be between six thousand (6000) to eight thousand (8000) would challenge the whole world; AMISOM has over 19000 troops, FGS has over 10000, American Special Forces are here, Turkey, UK and even Italians; all chasing Shabaab...

Initially, Al Shabaab were portrayed as disgruntled, unemployed, marginalized youth which is no longer the case. The combination of asymmetric nature and the emerging military hardware at their disposal shows the dynamic nature of military technology. It also emerged that some of the material used in the preparation of IEDs are readily available locally including things like fertilizers, charcoal and motorcycle batteries which cannot be banned because of their primary use. 
Similarly, the terrorist groups in the Horn of Africa seem to be so religious which plays a key role in changing the mind of many citizens unlike the military diplomacy activities. The case of Al Shabaab and AlQaida doctrines provide their members with an attractive set of spiritual benefits. They also use the spiritual benefits as part of the compensation package effectively as a screening mechanism which eases management of their recruits. Their campaigns bring the terror recruit a sense of purpose, being part of a team, unparalleled adventure, and often fame which was not witnessed in the conventional militaries in the Horn of Africa. In retrospect a respondent interviewed in Kismayu said:

Many times we deal with soldiers who have low morale because of unpaid salaries for a long time... this combined with mission stress... no wonder we have witnessed soldiers take their own lives or even kill their seniors...

While the above is the case in conventional militaries in intra state conflict environments, terrorist are able to create an image of an elite institution driven as much by the exigencies of the labour market as anything else both in Sudan and Somalia and hence a challenge to the use of military diplomacy in the region.

\section{iii. The Failed State Status Menace}

The conflicts in Somalia and the larger Sudan have been so devastating leading to long term famine, hunger and displacement. This fragile security therefore made many citizens to be left without any stable income because of collapsed government institutions due to poor leadership leading to sentiments of marginalization. An informant interviewed in Mogadishu on 16 December 2018 and had worked in both Somalia and Sudan said:

...out of frustrations and anger many of the citizens opted to join terrorists groups like al Shabaab and al Qaida in Somalia while the Janjaweed in Darfur recruited such youths...

The motivation to join these groups were however diverse. In Somalia the terrorist enjoy a lot of readily available human labour as the mass was vulnerable and unwilling to cooperate with the military. According to the respondent the locals easily cooperate with the criminal gangs who were willing to hire them and ultimately get paid for their services such as information givers or fighters. Therefore the terrorist groups saw an opportunity in the Horn of Africa in the sense that they had minimal cost with maximized outcome. However, with the mutating nature of militant groups in the Horn of Africa there is more motivation beyond poverty that keep the groups resilient.

Elsewhere, some sovereign states in the Horn of Africa also provide safe havens for jihadist idealist and hence a challenge to the use of military diplomacy in intrastate conflict management in the Horn of Africa. One of the countries that featured was Sudan when it hosted Osama Bin Laden for a long period of time in its own territory against the will of the international community. According to Downing (2006) Bin Laden enjoyed state protection and in return hired over five hundred Sudanese and paid them a monthly bonus of between $\$ 50$ and \$120 for their cheap labour (Downing, 2006). In Sudan therefore Bin Laden was strategic to attack the USA military personnel in Somalia who were there for the purposes of restoring peace. This was a similar case with Al Qaida in Afghanistan when it operated under the protection of national institutions. Their argument was that if they did not seek the protection of the state's infrastructures then they were vulnerable to attacks. In Sudan, the issue of state sovereignty and self-determination played a major role in exacerbating the conflict in the Horn of Africa country and in the same way proving a challenge for the use of military diplomacy. Also in the early 1990s Sudan due to its weak economy, provided an opportunity for insurgent groups who found the environment conducive for their activities. This is because insurgencies exploit ungoverned spaces within a fragile government.

The failed state status contributed to vulnerability of many citizens of the Horn of Africa posing a challenge to the use of military diplomacy. The terrorists in some of the places were therefore viewed as alternative governments charged with provision of governance services that the central government had failed to provide. For example, a respondent interviewed at the AU PSC said:

$\ldots$ in the early $1990 \mathrm{~s}$, the al Qaida had a well-structured pay to its members that was seen to be more attractive compared to other normal jobs, the salary of a married Mujahedeen is 6500 Pakistani Rupee, and 500 Rupee for every newborn while the salary of a bachelor Mujahedeen is 1000 Pakistani Rupee...

Another respondent interviewed in Mogadishu corroborated the above information that, in Somalia's areas under the stranglehold of al Shabaab, the population enjoy services of non- monetary nature like food 
supply, water supply, and even medical attention from al Shabaab. More importantly the al Shabaab judicial system is more expeditious than the bureaucratic government judicial system that takes a long time to determine a case. It is such benefits that endear the militants to the locals.

\section{iv. Competing Interests among Troop Contributing Countries}

From the study it was noted that most military interventions are politically driven and as such have political inclinations to the leaders. Most of the countries in conflict are not comfortable especially when the nations and their TCCs focus only on their national interests rather than the conflict. A respondent interviewed in Mogadishu on 14 December 2018 said:

Where there is deployment of foreign forces the national interests will always take Centre stage... conflicting interests are likely to strain relations and future anticipation of TCCs.

In other instances the military forces are viewed to compete for supremacy of who is in charge and more superior in solving the conflicts which was viewed as jeopardizing military diplomacy because it is about professionalism as each military is given its Area of Responsibility (AOR) in which roles are clearly designated according to the mandate of the Peace Support Operation as provided by the sanctioning body; either UN or AU.

The fact that national interests are critical to any nation's survival, when they are negatively skewed they become detrimental as they influence concerted efforts towards conflict management in the Horn of Africa. Competing interests by TCCs lead to lack of strategic consensus hence, difficult in coordinating operations. Competing interests may jeopardize the security and other humanitarian activities as well as prolong the conflict due to self-interest by the Troop Contributing Countries (TCCs) especially when other nations and their TCCs focus only on their national interests. One senior leader interviewed in Nairobi on 15 December 2018, concerned about competing interests said:

... it undermines the capabilities of each other and creates mistrust and breeds a state of superiority complex such that cooperation is lost.

These competing interests interfere with the peace processes. The host country deals with such countries which are perceived to be pursuing their interest's half- heartedly. They are usually weary of every move by the TCCs. Hence, such peace initiatives by such TCCs end up lacking local ownership. Every state takes seriously its national interests and guards it jealously. If a country feels that its national interests are jeopardized in a certain conflict it must express its diplomatic efforts:

.... Whether military or civil most of the competing interests can be resolved through the right chain of command and through repositions.

In some cases, some countries may flatly reject to collaborate and join hands with others in intrastate conflict management. Migue (2014), for example, notes that Ethiopia, although supporting Kenya's entry into Somalia and was engaged in fighting Al-Shabaab, refused to join AMISOM. Migue (2014) further found that competing interests were apparent in the sectorisation of the areas of responsibility whereby some TCCs felt that they should manage sectors that are along their borders. According to Migue (2014), this conflict of interest alienated some TCCs, which did not border Somalia like Burundi and Uganda while Al Shabaab and other factions might have seen this as a division within the military force. A respondent from Somalia further said that there were competing interests in terms of...

..... Competing interests were reported as one of the challenges impeding successful military diplomacy in the Horn of Africa. The military forces belonging to some countries were thought to be interested in the resources in Somalia (e.g. charcoal) others in running security companies and hotels. This led to mistrust among some of the military deployed to manage conflict in the country.

These sentiments are also shared by Barbosa (2014) in his address of the broad geographic areas of the African continent in his analysis of the challenges and difficulties that are encountered in military diplomacy. He provides an example of the challenges and difficulties associated with the deployment of military in managing conflict in the African continent, including the Horn of Africa. Using the Sino-US military diplomacy in managing conflict in the African continent, Barbosa (2014) points out that foreign vested interests and agenda are the main challenging factors in any successful military intervention and diplomacy in the continent. The two nations, among others, use their military to achieve ulterior motives 
which are in most cases unknown to the other party or African governments. This compromises effective military diplomacy in the region. For example, Barbosa (2014) observes that the diplomatic agenda of both the United States and Chinese toward the African continent cross in many different points, some of which are first, United States is much more aware of terrorist organizations and China is enjoying important political and economic position; secondly, terrorism, trade and arm sales; and thirdly, the Chinese and American competition for a leadership position in Africa, including the Horn of Africa, and support for African institutions. Contrary findings have been observed by a respondent from Uganda, interviewed in Nairobi on 15 December 2018 who observed that:

...Foreign vested interests were not the main challenging factor affecting the effective implementation of the strategies.

However, this was in contrast to other literature reviewed which showed that vested interests originating from outside the region partly affect the effective military diplomacy in the Horn of Africa. The mistrust that exists between countries whose military is used to intervene in internal wars is one of the factors that have been fronted as possible challenges to the implementation of effective strategies to foster military diplomacy. It follows therefore that the political interests and self-preservation agenda are not limited to foreign superpowers but are prevalent among sub-regional countries. Apart from the Ethiopia/ Eritrea example, Migue (2014) points out that the threat posed by Somalia insurgents to Kenya's national interests and survival was the main driving force for the deployment of the KDF in Somalia.

\section{v. Perceived Interference}

The interference by IGAD member states into the internal affairs of another member state has led to regional instability, in the sense that it has exacerbated hostility and worsened the rivalry among the competing states (Negash \& Tronvoll, 2000). In addition the following period of conflict highlights how regional member states have interfered with internal issues of other member states. The conflict in Djibouti in the 1990s between the ethnic community of Afar and Issa over the control of the state power was exacerbated by the interference of Somalia and Eritrea (Prendergast \& Mozersky, 2004).

Furthermore the Sudan civil war in 1993-2005, was characterized by interference from member states. Ethiopia, Eritrea and Uganda scaled the conflict by supporting their perceived allies; Uganda and Eritrea supported SPLM/A forces while Ethiopia supported the Khartoum government (Woodward, 2003). Even when African Union offered diplomatic military dimensions the interfering states still upheld national interests in the affected countries and this proved a challenge in as far as bringing peace and tranquility to the conflicting parties is concerned. Moreover, scholars have also noted that the intrastate conflicts have political connotations. This corroborates what one respondent said:

.... Conflicts in the Horn of Africa are determined by unique real politics played in the Horn of Africa... political finance is in the hands of individuals with political control and therefore violence is dispersed and contested based on these political dynamics.

The respondent was quoting from De Waal (2015) to justify the idiosyncratic challenge to the use of military diplomacy in the Horn of Africa. People with political means and will power ride on the backs of their populations whom they use as pawns to advance their selfish political ambitions so long as they have a political budget to recruit and deal with the masses. Therefore in intra state conflicts the leaders capitalize on poverty of the masses, majority being unsuspecting youth.

\section{Cold War Mentality in the Horn of Africa}

This section looks at various aspects of the findings that put the Horn of Africa into a cocktail of the cold war mentality. These include the Horn as a host to the cold war masters 9/11 and the antecedent Global Focus on the Horn of Africa, bureaucratic processes and how external policies are reengineered towards the Horn of Africa. These factors pose a challenge to military diplomacy influencing intrastate conflict management in the Horn of Africa.

\section{i. The Horn as a Host to the Cold War Masters}


During the cold war period that pitied the capitalist west against the communist east, led by the USA and USSR respectively, countries in the Horn of Africa were divided along capitalist and communist lines because they had to choose a line of survival. They even joined the Non-Aligned movement as a shield against the cold war rivalry. Arguably, most of these countries were comparatively weak, unstable and driven by internal conflicts and tensions. This in itself brought challenges whenever military intervention was needed amongst these states. For example, at one point, Somalia, Ethiopia and Sudan leaned toward the Soviet Union while Kenya and Uganda were on the United States side. It made either USA or USSR in their move not to have embassies in such countries they viewed to be supportive of the opponent.

According to Cohen (2006), Ethiopia, one of the countries that were pro Stalinist ideas under the regime of Mengistu Haile Mariam, was once a major ally of the USA. However, after it swung its alliance, it experienced difficulties in its relations with capitalist nations such as the USA. For instance, from 1981 the administration under Ronald Reagan and leaders of USA condemned Ethiopian rule of being repressive. The administration went ahead not to have an embassy in the country, an action which jeopardized its relations with countries such as Kenya who were pro the USA. (Cohen 2006). The division spilled over to the military interventions in the region and lasted over the years.

Initially, USA in the early 1970s had terminated its supply of ammunition to the Ethiopian regime citing the dismal human rights in the country (Cohen, 2006). However, Ethiopian administration responded by disabling USA communication facilities in Eritrea and even allowed military aid from the pro soviet states such as Cuba to defend Somalia aggression into its territory during the Ogaden war. There were three major events in Ethiopia that impacted greatly on the relations of countries in the Horn of Africa and military interventions. First, in 1952 the United Nations confederate Eritrea which was a former Italian colony, with Ethiopia, without a referendum of the Eritrean people. Second, there was Ethiopians insurgency that occurred mainly in Addis Ababa and in the northern province of Tigray. Young Tigrean revolutionaries sought Mengistu's overthrow and a change of political system. The insurgents in both provinces called themselves Marxists which again made the USA not to provide assistance to them, even though such political military activity was both fashionable and politically acceptable in Washington at the time. The rival political forces in Ethiopia rose to an extent that they were willing and able to use violence despite the fact that some were not strong enough, to give the government decisive support or to overthrow it.

According to Patman (2009), in such a crisis, the state lost legitimate authority and the military rule became the norm for implementing decisions. Ethiopia experienced an overt crisis after the deposition of Emperor Haile Selassie in September 1974. A combination of violent power struggles inside the revolutionary government and widespread rebellions brought the country to the verge of chaos by early 1977 . These were the circumstances in which the besieged government of Lieutenant Colonel Mengistu Haile Mariam looked to and received, in the form of Soviet-Cuban military intervention, external assistance for the resolution of internal problems (Patman, 2009).

Third, in 1989, the Ethiopian government got a notice from their Soviet mentors who were tired and wanted to see movement toward peace. This provided an opportunity for the Soviets to advise President Mengistu to seek help from the United States. However, Mengistu saw an opportune substitute of military support toward an alliance of anti-Arab alliance grouping Ethiopia, the United States, Israel and not the peaceful transition. Which until the very end of May 1991, Mengistu's regime aimed to win military victories in his unwinnable internal wars.

\section{ii. Post 9/11 and Global Focus on the Horn of Africa}

According to Barbosa, the super power military diplomacy toward Africa took a new turn with the 9/11 terrorist attacks in United States. Despite the fact that this happened on American soil, the shock wave was spread around the world and heightened the anxiety about the root cause of such attacks. The response of United States and other countries such as China was offensive. At the same time, this provided an opportunity for Washington to begin to include Africa in its strategic war on terror, and recognized that the continent gave the ideal environment for the non-state military groups to appear and spread due to its large number of refugees, potential militants, big stockpile of weapons and a large number of Muslims (Barbosa, 2014).

Therefore, the African continent once again provided an opportunity for military diplomacy by both China (Socialist) and United States (Capitalist). This therefore meant that the management of intrastate conflicts 
was at the whims and preponderance of the international community that dictated the funding. This is why a respondent interviewed in Mogadishu on 20 December 2019 posed:

It becomes difficult to even understand the real funders of al Shabaab... who sustains their motivation to advance their ideology?

However, in the processes this was due to the fact that the United States was now being challenged by China. Many scholars like Swistek (2012) viewed that the challenge of china to the US in Africa and more so the Horn of Africa was through the Forum on China-Africa Cooperation (FOCAC) which allowed these countries to pursue economic goals regardless of the military situation of different African nations, while proclaiming its undisputed commitment toward political and military non-interference. This is challenged further by the approach of China in which she deals with the Horn of Africa countries diplomatically through trade rather than aid. This contradicts the United States approach on how it relates with the region. The USA military diplomacy in the region is among others through distributing aid to different African nations, ostensibly, to spread democracy, human rights and other liberal ideas which is much more pronounced and lasting than their Chinese counterpart. To achieve their goals, the US deploys huge military actions in the region to ensure that their values of becoming universal are applied and exercised in Africa. This explains the reasons for foreign bases in the Horn of Africa like one respondent interviewed in Nairobi on 14 December 2018 said:

...the USA has military bases virtually in the entire Horn of Africa to advance and protect its vast interests in the Horn of Africa.

The Horn of Africa has witnessed a long history of internally inspired terror which threatens both domestic and international interests. This is true especially after East Africa has realized an increase in terrorism, partly due to the recent push for radical Islamist agenda in the region. It is believed that little attention from the West, the generally pacific and syncretistic African Islam is being swept aside by a militant Islamism imported from the Middle East. Therefore, due to the threat, the United States has increased its military efforts in the African continent to combat terrorism. They have done so through creation and establishment of a Combined Joint Task Force in Djibouti, in the Horn of Africa (Africa Task Force, 2018). This was part of the responses to the 9/11 attacks. In Somalia, the Americans have established a military base at Baledogle to mount airstrikes against al Shabaab.

Similarly, on $1^{\text {st }}$ October 2008, the USA launched the full sub-department under the Department of Defense that deals with African affairs, and named it the African Command (AFRICOM). Newly established department was quasi-military unit, where non-military operation actions could also be taken Barbosa (2014). AFRICOM is responsible in coordinating US military support by bringing the humanitarian work of the State Department, the US Agency for International Development (USAID), and other US government agencies to engage with Africa, under the direction of the US Department of Defense (Osikena, 2018).

Differently than issues of terrorism, the two major protagonists (USA and China) have competed in securing trade and markets for their arms in the Horn of Africa. This has been so on the Chinese side due to the rapid economic growth in the last 30 years which pressured domestic resources and forced its search for natural resources around the world, including African regions considered unstable by Western countries (Barbosa,2014). As earlier intimated by one key respondent, conflicts in the Horn of Africa provide fertile ground for USA and Chinese activities to flourish hence posing a major challenge to military diplomacy influencing intrastate conflict management in the Horn of Africa.

For instance, according to Hess (2010), on one hand, it was estimated that $25 \%$ of China's total oil imports come from Africa and in 2009 China received in 16\% and 6\% of its total crude oil imports from Angola and Sudan respectively which was a security priority for Beijing. On the other hand, approximately $2 \%$ of total Chinese arms production from 2005- 2010 was sold to the African continent (USA Annual Report to Congress, 2011). Even though this figure is relatively small, China places importance on the sovereign equality and respect for every government's right to determine its own domestic policies (Hess, 2010). It is therefore very clear that the urge for trade is an impediment towards the use of military diplomacy in intra state conflict management. While the use of the military is intended to manage conflicts, conflicts provide an opportunity for trade.

The race between China, US and the military intervention has also been witnessed through regional and other African Institutions such as the African Union (AU). However, this has left many members 
discontented and a challenge to the use of military diplomacy in the region. In some instances, the United States has put out a reasonable effort in reaching out to the AU and other African Institutions, but at same time it often undercuts its own efforts to resort to unilateral military action. Similarly the North American policy institutions like USAFCOM have been useful in tackling social issues like AIDS/HIV epidemic with its military arm, but falls far from the expectation while it maintains a rising level of weaponry being sold to the continent and oppose stricter UN weaponry regulation.

Such external interests have hurt the efforts of African countries in the use of military diplomacy to influence intrastate conflict management in the Horn of Africa. For example, when a government official openly blames embargoes for the inability to fight terrorism in Somalia following the car bomb attack at ExJunction in Mogadishu leading to more than 89 deaths and over 145 casualties, instead shifted the blame to orchestration by a foreign country. (Garowe Online 2 January 2020). Love \& Tronvoll (2009) observation that external policies may affect the manner and extent of the implementation of strategies meant to foster management of conflicts in Africa, applies also to intra-state conflicts. Cliffe et al (2009) go further and imply that the external policies might be the causes of conflicts in the region. For example, the relationship between Russia and America and the countries' external interests and policies are said to have influenced the management of conflicts in the Horn of Africa (Makinda 1982). According to the author USA and the Soviet Union define what takes place in the Horn of Africa within the perimeters of what they view as their national interests.

Further as pointed out by Docking (2001), the lack of political will that has been demonstrated by Western countries is also a major hindrance of successful implementation of military diplomacy sponsored by UN in the Horn of Africa. The Western nations are usually reluctant to be part of diplomatic interveners because few foreign states fear risking the life of their heavily experienced and skilled soldiers in poorly understood Horn of Africa nations where they are perceived to have no strategic and/or economic interests (Vines, 2013). As such they no longer wish to spend billions on costly military interventions each time conflict erupts in the Horn of Africa. A respondent interviewed in Juba on 16 October 2018 said:

In Darfur they left AMIS to grabble with financial and equipment challenges only to come and stabilize with UNAMID... they even increased Mission Subsistence Allowance upon establishment of UNAMID...

\section{Bureaucratic Process}

The use of military diplomacy in intrastate conflict management has experienced a myriad of challenges related to bureaucratic processes involved in the decision making processes ranging from the time when to intervene (Ripe moment), policy making process, policy assessment and the problem of Command and Control.

\section{i. 'Ripe Moment'}

Ethiopia, Kenya and Uganda, viewed as militarily stronger nations in the Horn of Africa have at different times during interventions in South Sudan and Somalia experienced a number of challenges in executing military diplomacy especially the ripe moment to launch the intervention. This was mainly through their leaders who perceive some weaker nations like South Sudan and Somalia as being intimidated by their military prowess. A respondent interviewed in Juba on 16 October 2018 said:

...these states have refused to go down especially with the fighting factions holding tight to what they perceive as important to them...

Therefore, until they achieve those goals it has remained a challenge to the military diplomacy in which case they are left with the option of either to back off or escalate the crisis without entering into a confrontation.

The military were torn on when they should intervene in an internal conflict that involved various factions like the case of OLF and TLF in Ethiopia and Nuer and Dinka in South Sudan. The Horn of Africa countries through the IGAD asked how the military should provide security both internal and external. However, some of the members had weak states that would only have provided their own security and have fear of external attacks from the regional superpowers. The fear of external aggression by those weak states resulted into tensions which hampered the role of the military in the region due to lack of coordination in diplomacy. Therefore, the question of what is the ripe moment for military intervention is a challenge that is reinforced by UN Charter provisions with regard to the policy of non-interference in internal affairs of member states. (UN Charter) 


\section{ii. Policy Making Process}

This study found out that whenever there were usable military options needed in the Horn of Africa, then special kinds of military capabilities were often needed for the use of condign diplomacy. This was due to their importance and more so sense of flexibility associated with them. However, the requirements for usable military options often were stringent and difficult to satisfy in reality because decision makers did not always have a clear sense of what the political objective was and when or whether the military option would achieve those objectives because of varied interests. However, those perceived opponents feared the unacceptability of threatened escalation because military diplomacy was only enhanced if the initial small steps taken against the opponent began to arouse unacceptable levels of warfare. This is why a respondent interviewed in Mogadishu on 17 December 2018 said:

...AMISOM is using its fighting components optimally, what is remaining is the political line of operations...is the Somali elite playing into the peace process?

From the foregoing question there is indication that without the synergy of all the parties to the conflict management the clarity that concerned a precise term of settlement in the Horn of Africa crisis might not have been sufficient enough and necessary to formulate specific demands with precise terms of settlements to the military.

\section{iii.Policy Making Assessment}

In the sphere of superpowers there is also the issue of policy makers. This posed a challenge to the use of military diplomacy in influencing intrastate conflict management in the Horn of Africa. However, according to Patman (2009), the application of military diplomacy through interventions is with the belief that the adversary state will not respond or only respond in a minimal fashion such as verbal condemnation. Conversely, two factors tend to shape policy-makers' assessments at the state level. Firstly, is the impact of ideology upon perceptions and secondly, is the quality of information available to the policy-makers and its effect to their perceptions. However, their overall decision will be determined on what side are the superpowers. For example, are the superpowers on one side of agreeing or disagreement to the policymaker's opinion?

Closely related to policy-making challenge is the bureaucracy related with decision making in the processes of military intervention, operation and exit. In this process the decision makers experience administrative pressures despite the long channels of planning, coordination and communication. A respondent interviewed in Mogadishu on 16 December 2018 alluded to the lengthy decision making process which incapacitates regional bodies like AU. He said:

As AU we will wait for some decisions from New York because the responsibility of international peace and security is the responsibility of the United Nations Organization...

Therefore, if decisions are made in New York then this poses a challenge to the use of military diplomacy in intrastate conflict management notwithstanding the fact that UN itself has its own inherent challenges. Therefore as Patman (2009) puts it, this in the end might subvert the aim and whenever military is involved the commitment can be enlarged beyond original expectations.

If the intervention outgrows its original purpose(s) the policy-makers become passengers rather than the drivers of a bureaucratic machine carried forward by the momentum of its own procedure. For example in terms of procurement a respondent interviewed in Nairobi on 15 December said:

If a bid is made, the process is too long that those who demanded the item even are rotated out of the mission before they actually use the item...

The procurement process takes too long. This has been a challenge in the Horn of Africa as those states from the region have been forced to finance most of their activities with little assistance from the international community leading to a standoff on the issues of reimbursement.

\section{iv. Command and Control}

From the findings of this study, the militaries that participate in intra state conflict management in the Horn of Africa have the opportunity to adhere to set standards and operate as one yet from there background they follow different doctrines as explained by a respondent: 
...Command and control is difficult because some of these militaries follow Eastern bloc kind of training like Burundi, Ethiopia, Djibouti while others like Kenya and Uganda follow west, yet others have a mixture including American, Italian and Turkish training doctrines...

Unification of doctrine into one without compromising national interests of the Troop Contributing countries poses a big challenge to command and control. Compounded with the above challenge, the force that is configured has to deal with adopting to war mentality. It becomes a command challenge to integrate operational activities, balance with diverse doctrine and diplomatic requirement to avoid strained relations with the respective Troop Contributing Countries, international norms must be adjusted to albeit the Garrison mentality.

\section{Inadequate Funding}

The challenge of funding has hampered effective use of military diplomacy in intrastate conflict management in the Horn of Africa. Somalia and South Sudan are countries that require infrastructural reconstruction occasioned by effects of intra state conflicts. This requires colossal amounts of money. The two regions in the Horn of Africa rely on donor funding yet the only support from African States is provision of militaries. The same militaries are limited in diplomacy because of modernization of forces hence avoid linking themselves directly but through proxies and peacekeeping activities, because use of military diplomacy as peace keepers was seen as more humane. Unlike military war fighting intervention, peacekeeping was viewed as a role that was taken on by a wide variety of different forces, from a number of different states (Bellamy et al, 2004). However, those military activities that took more period of time in a specific state in the region also required a lot of money and skilled personnel. For example, in Somalia the military personnel under AMISOM have had challenges emanating from logistical issues to sustain their long stay away from their homes which strained them. The countries that contributed to the AMISOM also had to invest a lot in the training of the elite personnel specifically to fit in time and space under their operation.

The challenge was much more to those military personnel who were specifically trained for the purpose of war-fighting. Consequently, they were forced to carry out other activities such as rebuilding roads, power stations and water supply tasks which the civilian had better and appropriate skills (Hanzen, 2002).

On the contrary, the African nations that have been left on their own to handle intrastate conflicts have been unable to do so appropriately. Holzgrefe (2003: 40) avers that the African countries with specific attention to Horn of Africa countries lack the mechanisms to handle these intrastate conflicts on their own. These military interventions require huge amounts of money for the operations to realize any gains and the source has to be reliable and valid (Festus, 2008). Again, financial resources are needed to purchase modern weapons, communication equipment, and utility as well as attack aircrafts among other requirements.

The interveners (the military) must be clothed and paid. For instance, when war broke out in Darfur in 2003, the Justice and Equality Movement (JEM), Sudanese militia (Janjaweed) and the Sudanese Army were immediately brawled in a vicious fight. In response the AU deployed African Mission in Sudan (AMIS) but AMIS was ill-equipped and so the area remained volatile despite the presence of the peacekeeping force. The Darfur Conflict laid Africa Mission in Sudan (AMIS) bare. This is supported by what a respondent said during a FGD held in Juba on 13 October 2018:

One would finish the tour of duty, his replacement arrives in the mission as the latter stays on waiting for arrears of more than three months...the wait would take more than one month...

It is, therefore, suffice to pose; could these shortcomings be mirrored to lack of capacity to battle with the challenges of conflict resolution that threatens to disrupt peace and security of the region? If funding was an issue then it would be irrelevant to increase the mission subsistence allowance. This is supported by the dollarization of the Somalia conflict to the extent that there is a lot of flow of money into the Horn of Africa.

\section{Other Opportunities}

In respect to the myriad challenges, there are various other opportunities that can be seized by militaries, regional and international bodies in the use of military diplomacy in intrastate conflict management. There is need for a holistic examination of the various measures that bodies like IGAD can adopt and implement with a view to ensuring that peace and security is achieved and sustained in the Horn of Africa. The first measure 
should be geared at addressing poverty by forging a strategic plan to end poverty in all its forms, everywhere. In the Horn of Africa and the Great Lakes Region, almost one out of every two people still lives in extreme poverty, more than four times greater than the world average. In this regard therefore, the intention to eradicate, not just reduce poverty, represents a major leap forward in terms of ambition and should be echoed in the commitment to leave no one behind (African Union, 2015).

To eradicate poverty which is one of the most pressing causes of conflict, insecurity and instability should not be seen as a technocratic exercise. For one to succeed, a leader must challenge power and vested interests. In this regard, a leader in a government must be prepared to take on vested interests and especially cartels that continue to benefit from poverty. A respondent interviewed in Juba on 13 October 2018 said:

Conflicts are run by cartels ranging from individuals to state organizations. Their only fear is that the conflicts don't escalate to hurt their interests...

Leaders in African governments thus have a responsibility to change policy priorities and spending allocations, and look to their own domestic resource mobilization. Secondly, leaders within the Horn of Africa and the Great Lakes Region must recognize that the foremost responsibility of government is protecting the life, liberty, and property of its citizens. To this end, key security instruments must be activated at all times and especially diplomacy which is a critical component to a nation's security. As the nation's foremost diplomat, a leader must thus strive to lead the effort to build and maintain relationships, coalitions, and alliances that help create the conditions for peace, contain or eliminate potential dangers from abroad before they can harm the country's citizens, and promote economic, social, and cultural cooperation. This should be inculcated into the youth through schooling, religious institutions and media which is a military diplomacy power tool called conditioning power.

Military diplomacy provides an opportunity for leaders within the Horn of Africa and the Great Lakes Region must also recognize that a country's own security is best guaranteed when its friends and neighbors are secure, free, and prosperous, and when they respect human rights and the rule of law. As a result, the leader should focus on efforts of resolving regional conflicts, countering global terror networks, combating internationally organized crime, and keeping weapons of mass destruction out of the hands of those that can harm their nations.

Finally, there's a need to ensure that the government that the leader in question leads makes viable national implementation plans identifying security threats as well as threats to peace and stability but also ones detailing clear and binding action plans. These national implementation plans should ensure the full participation of citizens and civil society in the delivery of these goals, and ensure that participatory monitoring systems are put in place to enable citizens to hold governments to account. Remember, the richer you are as a country, the more international responsibility you bear as well as responsibility to your own populations.

The success in the application of the conflict mechanisms outcomes or awards is contingent on opportunity to ease of implementation of the decisions and awards arising from the same such mechanism that requires extreme and outrageous implementation processes as less acceptable and successful in the current conflict management. On the contrary Adeneji reasons out that those mechanisms that provide more positive and favourable decisions with the ease of implementation are possible, acceptable and highly recognized with the communities. Communities and institutions are encouraged to adopt military diplomacy power tools that have tended to provide decisions with possible positive functional and favourable implementation and execution procedures.

The use of military diplomacy provides opportunities that take into consideration a more modern collaborative and cooperative or team approaches or a more individualist, rigid, and confrontational approach. Opiyo advocates for the adoption of the modern collaborative approach in the implementation of the outcomes noting that such systems provide room for more engagement, meetings and friendly exchanges and relationships. While noting that the traditional confrontational approach may be the norm among majority of the communities and societies in the resolution of conflicts execution. He nonetheless notes of the negative outcomes resulting from such ventures as in increased conflicts, grievances, loss of lives and property and increased hostilities.

Military power will remain important in framing and enabling how the world evolves, but unless practitioners get better at the civilian side of things it is difficult to understand how these Horn of Africa challenges can be effectively managed. Further, in diplomacy, Plessis (2008) sees the traditional peaceful 
and apparent instrument of foreign policy, and in the military, an approach of last resort involving the employment of the armed forces in offensive, defensive and deterrent capacities. (Plessis, 2008).

The challenges posed by conflicts provide an opportunity hence a comprehensive approach to security as advocated by scholars like Swistek (2012). In his interviews with a number of participants for his study on KDF's military diplomacy in Somalia, Migue, (2014) outlined a number of steps that were taken prior, during and after the military intervention in Somalia. The strategy included the involvement of several stakeholders, among them the following: The cabinet and parliament were approached to authorize the Operation Linda Nchi (Operation protect the country); Regular briefings to the Kenyan citizens and the media on the military operations in Somalia by an inter-ministerial committee which comprised Ministries of Foreign Affairs, Defense, Internal Security, and Information and Communication. Shuttle diplomacy was conducted at different levels to have a buy-in from other member states in East Africa. Initially only Uganda and Burundi had military presence in Somalia by 2007. There was also the use of multilateral approach whereby ambassadors from member states were actively involved in decision making to foster military diplomacy. Lobbying in regional organizations such as IGAD (Inter-Governmental Authority on Development), EAC (East African Community), and AU (African Union) for diplomatic leverage and finally, regular consultation among the CDFs (Chief of Defense Forces). The entire process has been validated by this study since there is a lot of engagement in Somalia and Sudan involving civilian-civilian, civilian - military and military-military notwithstanding the concept of the Carpenter's Toolbox.

\section{Conclusion}

From the findings of the study, it is clear that the obscurity of the military and the rubric in the understanding of military diplomacy poses a challenge for the military to influence intra state conflicts in the Horn of Africa. As earlier intimated, this is compounded by other challenges including the cold were mentality, influence of national interests on troop contributing countries leading to competing hegemonic interests. Consequently, the contingents work with a lot of suspicion against one another. Such acts occasion lack or minimum of sharing intelligence and information.

Peace support operations are expensive to manage yet the missions undertaken in the Horn of Africa lacks sustainable source of funds instead over rely on foreign funding and goodwill. With no sufficient funds, buying equipment and paying the staff becomes a big challenge. Emerging threats and clan dynamics are actualities that the use of military diplomacy was found to face as a challenge. Clan dynamics lead to uncertain political climate in the region.

In relation to challenges encountered in effecting strategies meant to foster management of intrastate conflicts and methods used to map out conflicts in intrastate conflicts in the Horn of Africa, the study established that foreign vested interests and agendas, mistrust that exists between countries whose military is used to intervene and competing interests among different military groups among others were some of the challenges met during intervention. Yet the challenges provide opportunities to rethink some of the strategies in order to ameliorate intrastate conflicts in the Horn of Africa. To do so requires creativity and rationality as postulated by the rational logic theory.

\section{References}

[1] Ayoob, M. (1995). The Third World Security Predicament: State Making Regional Conflict and the Continental System, Reenner Publishers

[2] Barbosa, A. J. F. (2014). The challenges and Difficulties of Sino-Us military diplomacy in the African continent. European Scientific Journal, ESJ, 10(10).

[3] Barry, B and Woever, O. (2006). Regions and Powers: The structure of International Security, Cambridge, Cambridge University Press.

[4] Bellamy, J. A (2012). Pragmatic Soldierism and the Dilemmas of Humanitarian Intervention: Millenium Journal of International Peace.

[5] Berridge, G. R. (2005) Diplomacy: Theory \& Practice, 3rd edition, Palgrave, Basingstoke.

[6] Brands H (2010) Latin America's Cold War. Cambridge: Harvard University Press.

[7] Clausewitz, V, (1968). On War, UK: Penguin.London.

[8] Cliffe, L., Love, R \& Tronvoll, K. (2009). Conflict and Peace in the Horn of Africa. Review of conflict in Sudan, Chad and the Central African Republic, Third World Quarterly, 20(1): 89-111 
[9] Cohen, H. (2000). Intervening in Africa: superpower peacemaking in a troubled continent. Springer.

[10] De Waal., A, (2015). The Real Politics of the Horn of Africa: Money, War and the Business of Power, Cambridge, Bridge Street, Polity Press.

[11] Downing W., (2006) Kenya, Eretria, Sudan, Ethiopia, Somalia, Djibouti. Harmony project. Combating terrorism center at west point.

[12] Edmunds, T, (2006). What are Armed Forces for? The Changing Nature of Military Roles in Europe. International Affairs 82(6), 1059-1075.

[13] Emma, L. (2012). Rendering Difference visible: The Kenyan State and its Somali Citizens. Oxford journals-social Science African Affairs Vol III Issue 445. Ethiopia, International Relations and Diplomacy, 4(12), 787-800.

[14] Fahmy, N. (2006). Terrorism is the World's Problem, 16 Duke Journal of Comparative and International Law pp 157-168.

[15] Freeman, C. W Jnr (1997). Arts of Power: Statecraft and Diplomacy. United States Institute of Peace Press, Washington DC.

[16] George, L. A, and Simons, E. W. (1994). The Limits of Coercive Diplomacy, Westview Press: Boulder.

[17] Hansen, S. J (2013). Al Shabaab in Somalia: The History and Ideology of a Militant Islamist Group. Oxford University Press.

[18] Healy, L. (2008) International Social Work: Professional Action in an Interdependent World, Oxford University Press, New York

[19] Hess, S and Aidoo, R. (2010). "Beyond the Rectories: Noninterference in China's African Policy". Africa and Asian Studies.

[20] Heywood, A (2000). Key Concepts in Politics, Basingstoke: Plagrave Macmillan.

[21] Holzgrefe, J. L. (2003). The humanitarian intervention debate, (eds) J. L. Holzgrefe and R. O. Keohane, Humanitarian Intervention: Ethical, Legal and Political Dilemmas, Cambridge: Cambridge University Press.

[22] Huntington, P. S. (1998). The Soldier and the State: Theory and Politics of Civil-Military Relations. London: Howard University Press.

[23] Janowitz, M. (2017). The professional soldier: A social and political portrait. Simon and Schuster.

[24] Lasswell, H. D. (1998). The garrison state. American journal of sociology, 46(4), 455468.

[25] Makinda, SM. (1982). Conflict and the superpowers in the horn of Africa. Third World Quarterly, 4(1): 93-103. DOI: 10.1080/01436598208419609. Management of Conflicts and Post Conflict Reconstruction. Addis Ababa: OSSREA; Oxford.

[26] Menkhaus, K. (2007). The Crisis in Somalia: Tragedy in Five Acts. London, Oxford University Press

[27] Migue, P. T. (2014) Military Diplomacy: A Case Study of Kenya Defence Forces in Somalia (20112012). MA Project, Institute of Diplomacy and International

[28] Mohani, C R, (2012). From Isolation to Partnership: The Evolution of India's military Diplomacy, ISAS, working paper, vol.14 no.4.

[29] Munk, G. L (2002). Rational Choice Theory in Comparative Politics. H.J. Wiarda, New Directions in Comparative Politics. Westview: Boulder.

[30] Osikena J. (2010) "Geo-politics beyond Washington: Africa's alternative security and development partnerships". Foreign Policy Center $<$ http://fpc.org.uk/fsblob/1203.pdf $>$ Nigeria: Chinese Workers Killed by Gunmen in Benisheikh $\langle\mathrm{BBC}>$

[31] Patman, R. G. (2009). The Soviet Union in the Horn of Africa: The diplomacy of intervention and disengagement (Vol. 71). Cambridge University Press.

[32] Plessis, A. (2008). Defence Diplomacy: Conceptual and Practical Dimension with specific reference to South Africa. Academic journal Article in Strategic Review for Southern Africa. Vol 30 no.2.Political instrument. USA: Brookings.

[33] Shea T C (2005): “Transforming Military Diplomacy,” Joint Force Quarterly38 50.

[34] Swistek, G. (2012). The Nexus between Public Diplomacy and Military Diplomacy in T. Lyons, Avoiding Conflict in the Horn of Africa: U.S. Policy Toward Ethiopia and Eritrea, Council on Foreign Relations, CSR NO. 21 (December 2006), pp. 6-8. 
[35] United Nations Security Council Resolution 2472 on the Security Situation in Somalia, 31 May 2019.

[36] USA Annual Report to Congress (2011) "Military and Security Developments involving the People's Republic of China.

[37] Wallin, M. (2015). Military Public Diplomacy. How the military influences foreign audiences. ASP,

[38] Walter R. Roberts, (2007) "What is Public Diplomacy? Past Practices, Present Conduct, Possible Future,” Mediterranean Quarterly 18:4: 37.

[39] Woodward, P. (1996). The Horn of Africa: Politics and International Relations, London: Tauris Academic Studies. 